\title{
低溫の內耳機能に及ぼす影響に 關寸万研究補遺
}

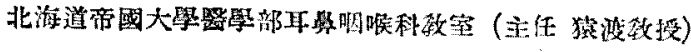 \\ 㗨學士 香宗我部范星
}

I 緒 言

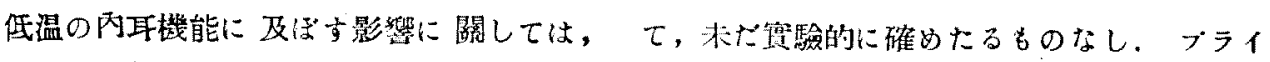

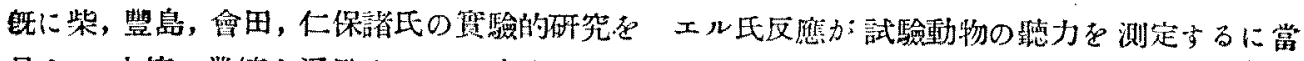

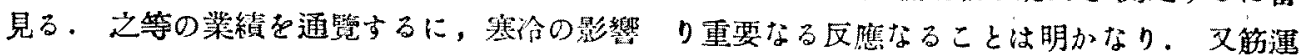
支局所の循環障碍若くは物理的影㗊による一 動が寒冷により障碍を受くることも認めらる

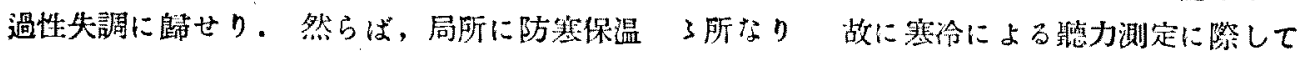

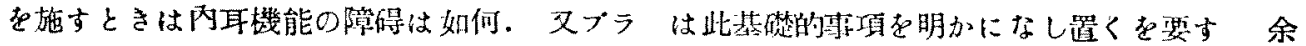
イエル氏反應檢查を行うに當り，前述諸家のは上述二つの點を陮明せんか篇め本實驗を企

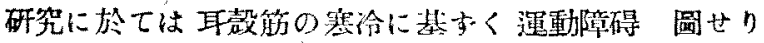

の有無に就て 嚾に仁保か之に言及せるのみに

\section{II 赛驗方法, 成績，考按}

1) プライエル氏反應

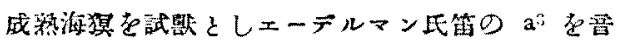

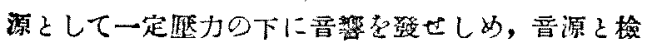

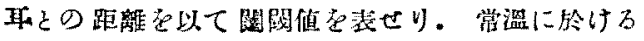

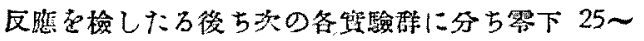
$32^{\circ} \mathrm{C}$ の低温室に揰大し低溫の影繁を检索ぜり。

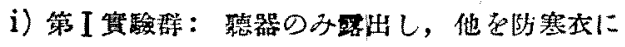

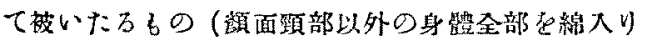
の袋狀衣服にて防寒し，四抆の先端はこれより出し て步行速動在自由らしし)。

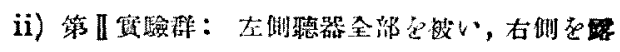

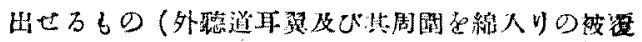
. 物にて保溫寸).

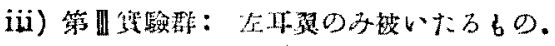

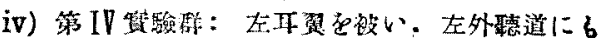

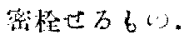

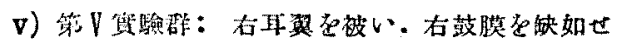
उ 60 .

貸驗成絽沃の如し.

\begin{tabular}{|c|c|c|c|c|c|c|c|c|c|}
\hline 熼驗群別 & 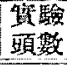 & 平均锝重 & 左右 & 㴧 & 低偲10分 & 低温30分 & 低溫60分 & 低溫9J分 & 低溫2時間 \\
\hline 第 I 筧驗群 & 5 & $654 \mathrm{~g}$ & $\begin{array}{l}\text { 左 } \\
\text { 右 }\end{array}$ & $\begin{array}{l}6.0 \mathrm{~m} \\
5.6 \mathrm{~m}\end{array}$ & $\begin{array}{l}1.1 \mathrm{~m} \\
1.4 \mathrm{~m}\end{array}$ & $\begin{array}{l}1.3 \mathrm{~m} \\
1.3 \mathrm{~m}\end{array}$ & $\begin{array}{l}1.4 \mathrm{~m} \\
1.8 \mathrm{~m}\end{array}$ & $\begin{array}{l}1.5 \mathrm{~m} \\
1.6 \mathrm{~m}\end{array}$ & $\begin{array}{l}0.8 \mathrm{~m} \\
1.1 \mathrm{~m}\end{array}$ \\
\hline 第 I 蟥驗群 & 5 & $684 \mathrm{~g}$ & $\begin{array}{l}\text { 左 } \\
\text { 右 }\end{array}$ & $\begin{array}{l}5.5 \mathrm{~m} \\
5.3 \mathrm{~m}\end{array}$ & $\begin{array}{l}1.3 \mathrm{~m} \\
0.5 \mathrm{~m}\end{array}$ & $\begin{array}{l}0.8 \mathrm{~m} \\
0.6 \mathrm{~m}\end{array}$ & $\begin{array}{l}1.1 \mathrm{~m} \\
0.6 \mathrm{~m}\end{array}$ & $\begin{array}{l}0.7 \mathrm{~m} \\
0.5 \mathrm{~m}\end{array}$ & $\begin{array}{l}0.5 \mathrm{~m} \\
0.3 \mathrm{~m}\end{array}$ \\
\hline 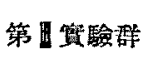 & 5 & $589 \mathrm{~g}$ & $\begin{array}{l}\text { 左 } \\
\text { 右 }\end{array}$ & $\begin{array}{l}5.2 \mathrm{~m} \\
4.3 \mathrm{~m}\end{array}$ & $\begin{array}{l}0.9 \mathrm{~m} \\
0.4 \mathrm{~m}\end{array}$ & $\begin{array}{l}0.9 \mathrm{~m} \\
0.5 \mathrm{~m}\end{array}$ & $\begin{array}{l}0.8 \mathrm{~m} \\
0.4 \mathrm{~m}\end{array}$ & $\begin{array}{l}0.8 \mathrm{~m} \\
0.4 \mathrm{~m}\end{array}$ & $\begin{array}{l}0.6 \mathrm{~m} \\
0.4 \mathrm{~m}\end{array}$ \\
\hline
\end{tabular}




\begin{tabular}{|c|c|c|c|c|c|c|c|c|c|}
\hline 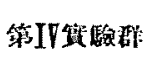 & 5 & $562 \mathrm{~g}\{$ & $\begin{array}{l}\text { 左 } \\
\text { 右 }\end{array}$ & $\begin{array}{l}5.6 \mathrm{~m} \\
5.5 \mathrm{~m}\end{array}$ & $\begin{array}{l}1.0 \mathrm{~m} \\
0.7 \mathrm{~m}\end{array}$ & $\begin{array}{l}0.8 \mathrm{~m} \\
0.7 \mathrm{~m}\end{array}$ & $\begin{array}{l}0.9 \mathrm{~m} \\
0.5 \mathrm{~m}\end{array}$ & $\begin{array}{l}0.9 \mathrm{~m} \\
0.6 \mathrm{~m}\end{array}$ & $\begin{array}{l}0.8 \mathrm{~m} \\
0.5 \mathrm{~m}\end{array}$ \\
\hline 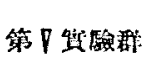 & 4 & $645 \mathrm{~g}\{$ & $\begin{array}{l}\text { 左 } \\
\text { 龙 }\end{array}$ & $\begin{array}{l}5.5 \mathrm{~m} \\
5.6 \mathrm{~m}\end{array}$ & $\begin{array}{l}0.9 \mathrm{~m} \\
0\end{array}$ & $\begin{array}{l}1.0 \mathrm{~m} \\
0\end{array}$ & $\begin{array}{l}0.8 \mathrm{~m} \\
0.1 \mathrm{~m}\end{array}$ & $\begin{array}{l}0.7 \mathrm{~m} \\
0.1 \mathrm{~m}\end{array}$ & $\begin{array}{l}0.9 \mathrm{~m} \\
0\end{array}$ \\
\hline 㻇照 群 & 5 & $665 \mathrm{~g}\{$ & $\begin{array}{l}\text { 左 } \\
\text { 右 }\end{array}$ & $\begin{array}{l}5.8 \mathrm{~m} \\
5.0 \mathrm{~m}\end{array}$ & $\begin{array}{l}0.9 \mathrm{~m} \\
0.6 \mathrm{~m}\end{array}$ & $\begin{array}{l}0.9 \mathrm{~m} \\
0.9 \mathrm{~m}\end{array}$ & $\begin{array}{l}1.0 \mathrm{~m} \\
1.0 \mathrm{~m}\end{array}$ & $\begin{array}{l}0.9 \mathrm{~m} \\
0.7 \mathrm{~m}\end{array}$ & $\begin{array}{l}0.8 \mathrm{~m} \\
0.6 \mathrm{~m}\end{array}$ \\
\hline
\end{tabular}

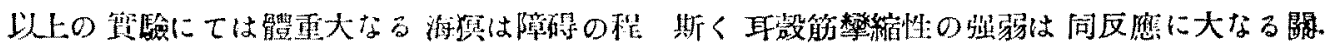

坆稍々輕く，寒冷に對する抵抗力の强弱は大

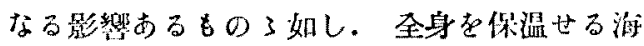
摸は 30 分顷より障碍恢復の傾向あり，60,90 分後には對照に比し障碍の程这稍々签く，2时 間媵には著明なる差買咇めす。

寒冷に對し 抵抗大なるものか: 障㥂輙度なる

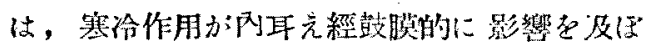
すのみならす、全身的寒伶の部分現象として

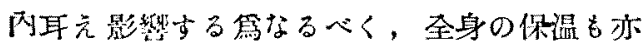
ブライエル氏反雔に大なる影響あるるのと調 うべし.

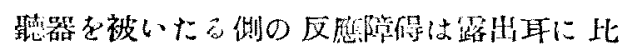

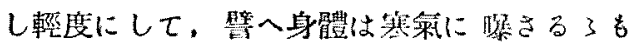
班器老保温する時は障碍され方少し。

單に耳复のみ被いたるるのも障碍されるこ

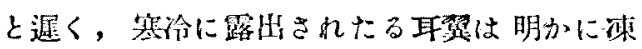
賃に陷り之か繁緛性低下し反應障碍著明なり。
係あり。寒冷作用下同反應を检する時は寒冷

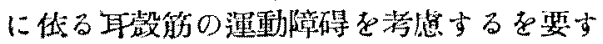
惯驗前正常の反應を呈せる海猽当鼓膜缺如後

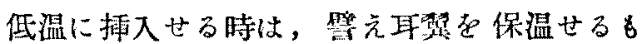
反雇全く現れぎるもの多し。

要之，罡洛に因るプライエル氏反應障碍の 原因は單一ならす，全身的藇冷のため韁器に

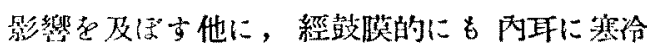
作用行われ，更に凍結に传る耳款筋の運動障 䅞も重要なる因子なりと認む。

\section{2）备轉後眼球震湄}

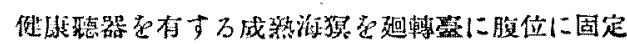

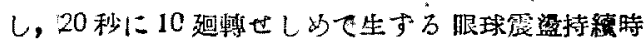

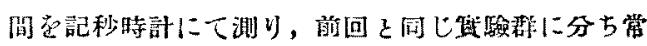

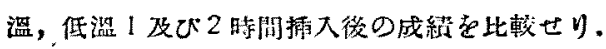

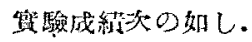

\begin{tabular}{|c|c|c|c|c|c|c|c|c|}
\hline 话领群别 & 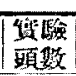 & 平均體重 & 呬䡛 & 常温の平均值 & 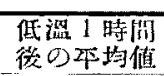 & 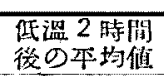 & 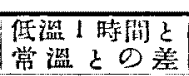 & 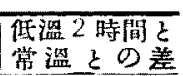 \\
\hline 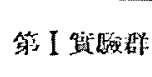 & 3 & $545 \mathrm{~g}\}$ & $\begin{array}{l}\text { 在 } \\
\text { 右 }\end{array}$ & $\begin{array}{l}8.5^{\prime \prime} \\
8.6^{\prime \prime}\end{array}$ & $\begin{array}{l}7.8^{\prime \prime} \\
7.8^{\prime \prime}\end{array}$ & $\begin{array}{l}7.0^{\prime \prime \prime} \\
6.7^{\prime \prime}\end{array}$ & $\begin{array}{l}\stackrel{1}{-} 0.7 \\
-0.8\end{array}$ & $\begin{array}{l}-1.5 \\
-1.9\end{array}$ \\
\hline 第 且啶验群 & 3 & $565 \mathrm{~g}\{$ & $\begin{array}{l}\text { 左 } \\
\text { 右 }\end{array}$ & $\begin{array}{l}8.9^{\prime \prime \prime} \\
9.0^{4}\end{array}$ & $\begin{array}{l}7.4^{\prime \prime \prime} \\
8.2^{\prime \prime}\end{array}$ & $\begin{array}{l}5.1^{\prime \prime} \\
7.4^{\prime \prime}\end{array}$ & $\begin{array}{l}-1.5 \\
-0.8\end{array}$ & $\begin{array}{l}-3.8 \\
-1.6\end{array}$ \\
\hline 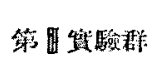 & 3 & $510 \mathrm{~g}\}$ & $\begin{array}{l}\text { 左 } \\
\text { 右 }\end{array}$ & $\begin{array}{l}8.7^{\prime \prime} \\
8.3^{\prime \prime}\end{array}$ & $\begin{array}{l}6.9^{\prime \prime} \\
7.0^{\prime \prime}\end{array}$ & $\begin{array}{l}5.7^{\prime \prime} \\
5.6^{\prime \prime}\end{array}$ & $\begin{array}{l}-1.8 \\
-1.3\end{array}$ & $\begin{array}{l}-3.0 \\
-2.7\end{array}$ \\
\hline 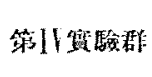 & 3 & $458 \mathrm{~g}\}$ & $\begin{array}{l}\text { 左 } \\
\text { 右 }\end{array}$ & $\begin{array}{l}7.4^{\prime \prime} \\
6.5^{\prime \prime}\end{array}$ & $\begin{array}{l}6.2^{\prime \prime} \\
5.9^{\prime \prime}\end{array}$ & $\begin{array}{l}5.5^{\prime \prime} \\
5.0^{\prime \prime}\end{array}$ & $\begin{array}{l}-1.2 \\
-0.6\end{array}$ & $\begin{array}{l}-1.9 \\
-1.5\end{array}$ \\
\hline 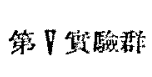 & 3 & $695 \mathrm{~g}$ & $\begin{array}{l}\text { 左 } \\
\text { 右 }\end{array}$ & $\begin{array}{l}8.5^{\prime \prime} \\
7.9^{\prime \prime}\end{array}$ & $\begin{array}{l}5.8^{\prime \prime} \\
6.5^{\prime \prime}\end{array}$ & $\begin{array}{l}3.6^{\prime \prime} \\
5.5^{\prime \prime}\end{array}$ & $\begin{array}{l}-2.7 \\
-1.4\end{array}$ & $\begin{array}{l}-4.9 \\
-2.4\end{array}$ \\
\hline 垹 照 碀 & 3 & $575 \mathrm{~g}\{$ & $\begin{array}{l}\text { 布 } \\
\text { 右 }\end{array}$ & $\begin{array}{l}11.3^{\prime \prime} \\
10.6^{\prime \prime}\end{array}$ & $\begin{array}{l}10.1^{\prime \prime} \\
9.3^{\prime \prime \prime}\end{array}$ & $\begin{array}{l}7.4^{\prime \prime} \\
6.8^{\prime \prime}\end{array}$ & $\begin{array}{l}-1.2 \\
-1.3\end{array}$ & $\begin{array}{l}-3.9 \\
-3.8\end{array}$ \\
\hline
\end{tabular}

全身の防寒保温を施せる海猽は，對照程著 敝膜を缺し中耳貯內に直接寒冷の作用を受け

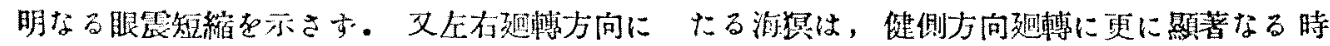

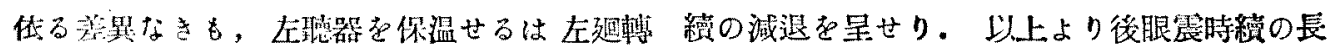

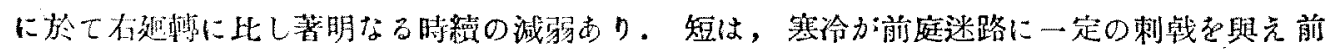


庭器の興焦性を減弱する第にして, 全身的些 冷の結果として起り得るも, 读器保温の有照

\section{III 結}

1）ブライエル氏反應

i）對照は低温扱入後 10 分にして反㮣障碍 され，60 分頃より恢復し始めたるも，90分に して再び著明なる障碍を呈したり。

ii）體重大なる，或は全身防然せる谁㨠 は 30 分後より障碍恢復の徽現れ, 全經過旮通 し對照に比し障碍の程度稍々繋し。

iii) 䖥器保温せるものは，露出耳に比し 障碍遥に暧度なり。

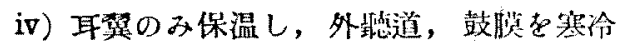
に懪したるものと雖も障碍輕度なり

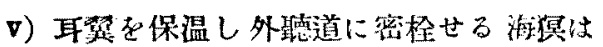
障碍暧微なりしも，寒冷に因る全身旁弱の著 しきるのは差異を認めす

vi）攱膜缺如せる海㨠は，譬え耳营を保温
も亦大なる關係ありと帽うぶし。

\section{論}

せるも反府現れす。

2) 迴轉後眼球是盜

i) 對照の眼震持續的低温 1 時閒㨉入後 1.2 $\sim 1.3$ 秒, 2 時間啳は $3.8 \sim 3.9$ 秒短䑿せ り.

ii）全身防寒を施せる海冥仙，對照に比し 眼震時續の娍迟皧度なり。殊に低温 2 時間挿 入後に於て然り。

iii）一側の聽器を保温せるものは該側力向 迴轉に際し 時續の減泿著しく，反對側呬轉と の落異大なり。

iv) 耳翼のみ被い，外德道の保温を施さざ りしものは左存方向迴轉の差晎比较的㙷著な ら方。

v）一側の鼓膜缺如せるものは，左右方向 趣轉に著明なる差異あり。 